УДК: $630.1+581.6+581.524+(477.63)$

\author{
В. М. Савосько, М. О. Квітко \\ Криворізький державний педагогічний університет
}

\title{
ЕКОЛОГІЧНА ОБУМОВЛЕНІСТЬ СУЧАСНОГО СТАНУ ЛІСОВИХ КУЛЬТУРФІТОЦЕНОЗІВ КРИВОРІЖЖЯ
}

Досліджено лісові культурфітоценози Криворіжжя, які репрезентують усі основні різновиди штучних деревних насаджень регіону. Сучасний стан лісових культурфітоценозів характеризусться несформованою вертикальною структурою (в більшості випадків відсутні яруси підліску та чагарників); ущільненими посадками першого та другого ярусів; невисокими значеннями запасів стовбурної деревини; ослабленим та сильно ослабленим життєвим станом деревостану.

Ключові слова: лісові культурфітоценози, життєвий стан, Криворіжжя.

В. Н. Савосько, М. А. Квитко

Криворожский государственный педагогический университет

\section{ЭКОЛОГИЧЕСКАЯ ОБУСЛОВЛЕННОСТЬ СОВРЕМЕННОГО СОСТОЯНИЯ ЛЕСНЫХ КУЛЬТУРФИТОЦЕНОЗОВ КРИВОРОЖЬЯ}

Исследованы лесные культурфитоценозы Криворожья, представляющие все основные разновидности искусственных древесных насаждений региона. Современное состояние лесных культурфитоценозов характеризуется несформированной вертикальной структурой (в большинстве случаев отсутствуют яруса подлеска и кустарников); уплотненными посадками первого и второго ярусов; невысокими значениями запасов стволовой древесины; ослабленным и сильно ослабленным жизненным состоянием древостоя.

Ключевые слова: лесные культурфитоценозы, жизненное состояние, Криворожье.

$$
\begin{gathered}
\text { V. M. Savosko, M.O. Kvitko } \\
\text { Kryvyi Rih State Pedagogical University }
\end{gathered}
$$

\section{ECOLOGICAL DETERMINATION OF CURRENT STATE OF CULTIVATED FOREST COMMUNITY IN KRYVORIZHZHYA}

Aim: to analyze the current state of cultivated forest community in Kryvorizhzhya from exposure to environmental factors areas of their deployment.

As objects of research were selected the several cultivated forest community in Kryvyi Rih ore mining region. These forest communities representing all major types of artificial tree plantations in the region: objects Landscape Architecture, sanitary protective, waterproof and municipal forest protection zone. Cultivated forest communities are located in contrasting environmental conditions and at the same time present the main varieties of tree plantations in the region. As controls were used natural forest communities (Gurivsky Forest).

Research methods. Monitoring plots were laid within forest communities at Kryvorizhzhya. At monitoring sites found out vertical structure of vegetation; performed measurements of height and trunk diameter at a height of $1.3 \mathrm{~m}$ trees first or third tiers; determined the vitality of trees. The life condition of plantations was established by V.A. Alekseev. Stock stem wood was calculated by M.P. Anuchin.

Assessment of environmental conditions of forest communities'territory. As known environmental conditions of plant growth and development are determined by the influence of natural and anthropogenic factors. Moreover, among the most important natural factors are soil conditions, soil fertility and moisture. While both anthropogenic atmospheric pollutants environmental factors are the most critical for the growth and development of woody plants.

(C) В. М. Савосько, М. О. Квітко, 2016 
According to the atmospheric assessment by Professor I.A. Dobrovolsky emit air pollution zones: 1) significant pollution zone, 2) relatively large area of contamination, 3) medium contamination zone, 4 ) minor contamination zone, 5) periodic small area of contamination. Comparing the effect of natural and anthropogenic factors, we have the selection zone ecological conditions of cultivated forest community growth and development, namely: 1) Zone of favorable environmental conditions; 2) Zone of relatively favorable environmental conditions; 3) Zone of relatively unfavorable environmental conditions; 4) Zone adverse environmental conditions.

Forest communities in the area of favorable environmental conditions. Forest communities, located in favorable environmental conditions, are natural forest have been formed with oak Quercus robur $\mathrm{L}$. These plant communities are characterized formed completely vertical structure. The relative standard state plantations assessed as well ( 86 points by V.A. Alekseev).

Cultivated forest communities in the areas of other environmental conditions. Forest plant communities formed by oak Quercus robur, ash Fraxinus excelsior, elm smooth Ulmus laevis. In plantations partially formed vertical structure, no second and third tier or a small number of seedlings. The relative state of life of our plantations identified as easing (55-65 points by V.Y. Alekseev).

Conclusions. The current state of cultivated forest community in Kryvorizhzhya, which were created in 30-60 years of the twentieth century and located in various environmental conditions determined by the combined influence of anthropogenic and natural factors.

Cultivated forest community in Kryvorizhzhya characterized by: immature vertical structure (in most cases there are no tiers undergrowth and shrubs); compacted planting the first and second tiers; low inventory values stem wood; weak and very weak relative state of life stand. Our results prospectively used to design artificial tree plantations in conditions steppe climate and the background aerotechnogenic pollution and during phytorecuctivation and phytolandreclamation work in industrial regions.

Keywords: cultivated forest community, state of life, Kryvorizhzhya.

У наш час лісові культурфітоценози (лісові КФЦ) є важливим фактором оптимізації умов життєдіяльності людини у промислових регіонах. Штучні деревні насадження позитивним чином впливають на температурний, світловий та вітровий режим атмосферного повітря промислових міст, з високою ефективністю знешкоджують, а також запобігають поширенню атмосферних пилогазових полютантів [3; 4; 7; 9; 18].

Численними дослідженнями встановлено, що в умовах окремих промислових регіонів, які знаходяться у степовій зоні, деревні рослини зазнають подвійного негативного впливу: посушливості клімату та забруднення довкілля [4; 12 ; $14 ; 15 ; 19]$. Як наслідок, вони істотно пригнічуються, завчасно старіють та значно зменшують свою фітомеліоративну ефективність $[5 ; 9 ; 13]$. Тому на сьогодні залишається актуальним дослідження сучасного стану лісових культурфітоценозів, що зростають у промислових регіонах степової зони України, зокрема на Криворіжжі.

Криворізький гірничо-металургійний регіон - це особливий та унікальний природно-територіальний комплекс України, де діють надпотужні підприємства з видобування руди, іiї збагачення та переробки. Щорічно в регіоні з надр землі вилучається понад 100 млн. т залізної руди, виробляється близько 60 млн. т залізорудної продукції збагачення (агломерату, концентрату та обкотишів), виплавляється 6-7 млн. т чавуну та 5-6 млн. т сталі. Крім того, в регіоні утворилося понад 20 тис. га техногенних ландшафтів $[3 ; 8 ; 10]$. Ось чому створення на Криворіжжі стійких лісових культурфітоценозів є дуже актуальною проблемою.

Окремими аспектами та найбільш актуальними питаннями стану штучних лісових насаджень Криворізького регіону займалися викладачі кафедри ботаніки та екології Криворізького педагогічного інституту (I. А. Добровольський, 
В. I. Шанда [8; 20]), науковці Криворізького ботанічного саду НАН України (А. Є. Мазур, М. Г. Сметана та В. Д. Федоровський $[16 ; 19])$ та ін. $[4 ; 6 ; 7]$.

Зазначеними вище та іншими дослідниками було вивчено історію створення штучних деревних насаджень Криворіжжя, проаналізовано їх лісорослинні умови та розглянуто окремі питання їхнього стану. Однак, в основному, ці пошуки були проведені лише у 70-80 pр. минулого століття. При цьому деревні насадження найчастіше розглядалися з точки зору ботаніки, в той час як практично не проводилося їх вивчення з позиції екології.

Як відомо, штучно створені деревні насадження, залишені після утворення намету крони поза увагою людини, самостійно розвиваються за відповідними екологічними законами та певними тенденціями. При цьому, залежно від флористичного складу насаджень, їх вертикальної структури та умов розміщення, надалі можливий як прогрес, так і регрес цих новоутворень степу. Ось чому з'ясування факторів впливу на майбутній розвиток штучних деревних насаджень та механізмів їх дії дає змогу зрозуміти філософію цього явища. В подальшому, спираючись на отримані результати, $\epsilon$ можливість впровадити виключно таки заходи, котрі будуть спонукати дію природних сил лісових культурфітоценозів та їх позитивний розвиток.

Отже, на нашу думку, спираючись на все зазначене, залишається актуальним з’ясування залежності сучасного стану лісових культурфітоценозів Криворіжжя від впливу екологічних факторів територій, де вони розміщені. Розгляд цієї проблеми було обрано за мету даної роботи.

Матеріали і методи досліджень. Об'єктами досліджень були обрані лісові культурфітоценози Криворіжжя, які розташовані в контрастних екологічних умовах та репрезентують усі основні різновиди штучних деревних насаджень: об’єкти садово-паркового господарства (Довгинцівський та Веселотернівський дендропарки), санітарно-захисні (С33 ПАТ «Арселор Міттал Кривий Ріг»), водозахисні (лісосмуги Карачунівського водосховища і р. Бокова, околиці с. Волове) та міські лісозахисні пояси (урочища «Дубки», «Дніпропетровського шосе», «Кільце Косіора»). Як контроль були використані природні насадження Гурівського лісу (Долинський р-н, Кіровоградська обл.), що розташовані у заплаві р. Бокова та віддалені на 30 км від промислових підприємств.

У межах зазначених лісових культурфітоценозів Криворіжжя було закладено моніторингові ділянки, де протягом 2013-2015 років за загальноприйнятими методиками [2] 3'ясовували вертикальну структуру насаджень; проводили виміри висоти та діаметр стовбуру на висоті 1,3 м дерев першого-третього ярусів; визначали за ознаками крони, листків та гілок життєвість дерев. Життєвий стан насаджень встановлювали за В. А. Алексєєвим [1]. Запас стовбурної деревини розраховували за М. П. Анучиним [2].

Результати i їх обговорення. Оцінка екологічних умов території розміщення. Як відомо, ріст та розвиток деревних рослин обумовлюється інтегральним впливом екологічних факторів, які, за класичною схемою, поділяються на природні та антропогенні [4; 7; 11]. На Криворіжжі серед природних екологічних факторів деревних насаджень найбільш важливими $є$ едафічні умови: родючість (трофність) та, особливо, вологість (гідрологічність) грунтів. У класичній схемі Погребняка - Алексєєва виділяють певні едафічні характеристики ділянок лісу, при цьому трофність грунтів коливається від бору до діброви (або груди), а гідрологічні умови коливаються від дуже сухих до мокрих [11; 18]. В умовах Криворіжжя трофність грунтів представлена здебільшого сугрудами та грудами (C та D). У той же час їх вологість охоплює практично увесь спектр класифікаційної схеми.

Серед антропогенних екологічних факторів атмосферні забруднювачі є найкритичнішими для росту та розвитку деревних рослин $[4 ; 6 ; 9 ; 18]$. На нашу дум- 
ку, найбільш адаптованою до умов регіону та перевіреною $[17 ; 20]$ є схема оцінки стану атмосфери професора I. А. Добровольского [8]. Згідно з нею доцільно виділяти такі зони забруднення атмосфери: 1) зона значного забруднення (333), 2) зона порівняно значного забруднення (ЗПЗ3), 3) зона середнього забруднення $(3 \mathrm{C} 3), 4)$ зона незначного забруднення (3Н3), 5) зона періодичного незначного забруднення (ЗПНЗ).

Поєднуючи можливу дію природних та антропогенних факторів, нами було розроблено шкалу екологічних характеристик територій розташування лісових культурфітоценозів Криворіжжя (табл. 1).

Таблиия 1

Інтегральна екологічна оцінка території розташування лісових культурфітоценозів Криворіжжя

\begin{tabular}{|c|c|c|c|c|c|}
\hline \multirow{2}{*}{$\begin{array}{c}\text { Грунтово- } \\
\text { гідрологічні умови }\end{array}$} & \multicolumn{5}{|c|}{ Зони забруднення атмосфери (за проф. І.А. Добровольським) } \\
\hline & 333 & ЗПЗ3 & $3 \mathrm{C} 3$ & $3 \mathrm{H} 3$ & ЗПНЗ \\
\hline Сухі сугруди С1 & - & $\begin{array}{c}\text { Урочище } \\
\text { «Дніпропет- } \\
\text { ровське } \\
\text { шосе» }\end{array}$ & $\begin{array}{l}\text { Довгинців- } \\
\text { ський } \\
\text { дендропарк }\end{array}$ & \multirow{2}{*}{$\begin{array}{c}\text { Водозахисні } \\
\text { насадження } \\
\text { Карачунів- } \\
\text { ського водо- } \\
\text { сховища }\end{array}$} & - \\
\hline $\begin{array}{l}\text { Свіжі } \\
\text { сугруди С2 }\end{array}$ & $\begin{array}{c}\text { Насадження } \\
\text { С33 } \\
\text { «Арселор } \\
\text { Міттал } \\
\text { Кривий ріг» }\end{array}$ & $\begin{array}{c}\text { Урочище } \\
\text { «Кільце } \\
\text { Касіора» }\end{array}$ & - & & - \\
\hline Вологі груди D3 & - & - & $\begin{array}{l}\text { Урочище } \\
\text { «Дубки» }\end{array}$ & - & $\begin{array}{c}\text { Водозахисні } \\
\text { насадження } \\
\text { р. Бокова }\end{array}$ \\
\hline $\begin{array}{l}\text { Сирі } \\
\text { груди D4 }\end{array}$ & - & - & - & $\begin{array}{c}\text { Дендропарк } \\
\text { «Веселі } \\
\text { Терни» }\end{array}$ & Гурівський ліс \\
\hline
\end{tabular}

Примітка. Зони забруднення атмосфери наведено у тексті.

Співставляючи ефект дії природних (грунтово-гідрологічних умов) та антропогенних факторів (рівень забруднення атмосферного повітря), нами було виділенно зони екологічних умов росту та розвитку лісових КФЦ Криворіжжя, а саме: 1) зона сприятливих екологічних умов (ЗСЕУ); 2) зона відносно сприятливих екологічних умов (ЗВСЕУ); 3) зона відносно несприятливих екологічних умов (ЗВНЕУ); 4) зона несприятливих екологічних умов (ЗНЕУ).

Стан лісових культурфітоценозів у зоні сприятливих екологічних умов. Лісові фітоценози, які знаходяться у сприятливих екологічних умовах, представлені природними насадженнями Гурівського лісу, що розташовані в заплаві. Вони сформувалися 3 домінуванням дуба звичайного (Quercus robur L.), орієнтовний вік - 150-160 років (табл. 2).

Лісові фітоценози Гурівського лісу характеризуються (табл. 2) повністю сформованою вертикальною структурою. При цьому природна щільність дерев I - III ярусів становить 1200 шт./га, їх висота - 18 м, а діаметр стовбурів - 20 см. За 150 років функціонування фітоценозу запас стовбурної деревини становить 530 м³/га. Життєвий стан насаджень оцінений як здоровий (86 балів за шкалою В. А. Алексєєва). Загалом показники сучасного стану природного фітоценозу Гурівського лісу є найбільш оптимальними та можуть будуть використані в подальших дослідженнях як контрольні.

Стан лісових культурфітоценозів у зоні відносно сприятливих екологічних умов. Лісові фітоценози, які зростають у відносно сприятливих екологічних умовах, представлені урочищем «Дубки» (центральне Криворіжжя, заплава р. Саксагань); дендрологічним парком «Веселі Терни» (північне Криворіжжя, заплава р. 
Саксагань); лісовим масивом околиць с. Волове (Криворізький сільський р-н, заплава р. Бокова).

Табличя 2

Стан лісових культурфітоценозів Криворіжжя в різних екологічних умовах

\begin{tabular}{|c|c|c|c|c|c|c|c|}
\hline \multirow{2}{*}{ № } & \multirow{2}{*}{\multicolumn{3}{|c|}{$\begin{array}{c}\text { Показники стану } \\
\text { лісових культурфітоценозів }\end{array}$}} & \multicolumn{4}{|c|}{$\begin{array}{l}\text { Зони екологічних умов росту та розвитку } \\
\text { лісових культурфітоценозів }\end{array}$} \\
\hline & & & & ЗСЕУ & ЗВСЕУ & ЗВНЕУ & ЗНЕУ \\
\hline 1. & \multirow{3}{*}{ 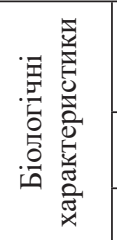 } & \multicolumn{2}{|c|}{ Домінуючі види } & $\begin{array}{l}\text { Дзв, Ясзв, } \\
\text { Клпл }\end{array}$ & $\begin{array}{l}\text { Дзв, Ясзв, } \\
\text { Вгл, Кляс, }\end{array}$ & $\begin{array}{c}\text { Дзв, Ясзв, Акб, } \\
\text { Дчерв, } \\
\text { Лсл, Сзв }\end{array}$ & $\begin{array}{l}\text { Дзв, Ясзв, } \\
\text { Кляс, Вгл }\end{array}$ \\
\hline 2 & & \multicolumn{2}{|c|}{ Походження } & Природне & $\begin{array}{c}\text { Природне } \\
\text { штучне }\end{array}$ & Штучне & Штучне \\
\hline 3 & & \multicolumn{2}{|c|}{ Вік, роки } & $150-160$ & $110-50$ & $50-80$ & $60-80$ \\
\hline 4 & \multirow{5}{*}{ 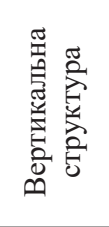 } & \multicolumn{2}{|c|}{ AI } & ++ & ++ & ++ & ++ \\
\hline 5 & & \multicolumn{2}{|c|}{ AII } & ++ & ++ & +- & ++ \\
\hline 6 & & \multicolumn{2}{|c|}{ AIII } & ++ & +- & +- & +- \\
\hline 7 & & \multicolumn{2}{|c|}{$\mathrm{Fr}$} & ++ & +- & -+ & -+ \\
\hline 8 & & \multicolumn{2}{|c|}{$\mathrm{H}$} & ++ & ++ & +- & -- \\
\hline 9 & \multirow{8}{*}{ 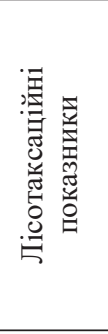 } & \multirow{2}{*}{ N, шт./га } & Min & \multirow{2}{*}{1200} & 225 & 525 & 525 \\
\hline 10 & & & Max & & 1175 & 2600 & 1600 \\
\hline 11 & & \multirow{2}{*}{$\mathrm{D}, \mathrm{cm}$} & Min & \multirow{2}{*}{18} & 16 & 12 & 9 \\
\hline 12 & & & Max & & 51 & 23 & 29 \\
\hline 13 & & \multirow{2}{*}{$\mathrm{H}, \mathrm{м}$} & Min & \multirow{2}{*}{20} & 12 & 8,5 & 13 \\
\hline 14 & & & Max & & 19 & 16 & 18 \\
\hline 15 & & \multirow{2}{*}{$\mathrm{V}, \mathrm{m}^{3} /$ га } & Min & \multirow{2}{*}{530} & 115 & 58 & 120 \\
\hline 16 & & & Max & & 460 & 265 & 370 \\
\hline 17 & \multirow{4}{*}{ 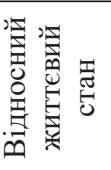 } & \multirow{2}{*}{ Бал } & Min & \multirow{2}{*}{86} & 80 & 75 & 59 \\
\hline 18 & & & Max & & 95 & 89 & 76 \\
\hline 19 & & \multirow{2}{*}{ Оцінка } & Min & \multirow{2}{*}{ здорові } & здорові & ослаблені & ослаблені \\
\hline 20 & & & Max & & здорові & здорові & ослаблені \\
\hline
\end{tabular}

Примітка. Скорочення назв деревних порід у формулах деревостану: Дзв - дуб звичайний Quercus robur; Клпл - клен польовий Acer campestre L.; Ясзв - ясен звичайний Fraxinus excelsior L.; Вгл - в'яз гладкий Ulmus laevis Pall.; Кляс - клен ясенелистий Acer negundo L.; Акб - акація біла Robinia pseudoacacia L.; Дчерв - дуб червоний Quercus rubra L.; Лсл - липа серцелиста Tilia cordata L.; Сзв - сосна звичайна Pinus sylvestris L.

Встановлено, що I-II яруси лісових КФЦ зони відносно сприятливих екологічних умов сформовані дубом звичайним (Quercus robur), ясенем звичайним (Fraxinus excelsior), в'язом гладким (Ulmus laevis). Крім того, у III ярусі також присутні клен ясенелистий (Ace negundo), клен польовий (Ace campestre), тополя біла (Populus alba L.), клен гостролистий (Acer platanoides L.), в’яз шершавий (Ulmus glabra Hudson), шовковиця чорна (Morus nigra L.), верба плакуча (Salix fragilis L.), клен татарський (Acer tataricum L.). Слід зазначити, що лісові КФЦ цієї зони мають як природне, так і штучне походження 3 віком 50110 років.

Території лісових КФЦ, які розташовані у відносно сприятливих екологічних умовах, мають достатній рівень зволоження грунтів, так як знаходяться в заплавах річок. Однак на ділянках спостерігається значний вплив антропогенно-рекреаційного та аеротехногенного навантаження (табл. 1). У лісових КФЦ частково сформована вертикальна структура, подекуди відсутній III ярус або є незначна кількість підросту. Щільність насаджень перших трьох ярусів коливається в межах від 225 до 1175 шт/га. Висота цих ярусів має позначення 13-19 м. 
Показники діаметрів стовбурів становлять $16-52$ см. За час функціонування запас деревини лісових фітоценозів сягає значень 11-460 м³/га (табл. 2). Життєвий стан цих насаджень нами визначений як здоровий (80-95 балів за шкалою В. Ю. Алексєєва).

Стан лісових культурфіточенозів у зоні відносно несприятливих екологічних умов. Лісові КФЦ Довгинцівського дендропарку та водозахисні насадження Карачунівського водосховища належать до зони з відносно несприятливими екологічними умовами.

Лісові КФЦ цієї зони сформовані дубом звичайним (Quercus robur), ясенем звичайним (Fraxinus excelsior), акацією білою (Robinia pseudoacacia), дубом червоним (Quercus rubra), липою серцелистою (Tilia cordata), сосною звичайною (Pinus sylvestris). Усі насадження мають виключно штучне походження і були створені приблизно 50-80 років тому. Слід наголосити, що едафотопи зони з відносно несприятливими екологічними умовами характеризуються недостатнім рівнем зволоження (табл. 1). Крім того, на ділянках відмічається негативний вплив рекреації мешканців та аеротехногенного забруднення підприємств міста.

За результатами наших досліджень, вертикальна структура лісових КФЦ цієї зони несформована, з малорозвиненим II та III ярусом, а також практично відсутнім чагарниковим ярусом. Трав'янистий ярус на усіх моніторингових ділянках також недостатньо виражений (табл. 2). Встановлено, що щільність насаджень I, II, III ярусів коливається від 525 до 2600 шт/га. Висота цих ярусів - 8,5-16 м, діаметр стовбурів - 12-23 см. За час функціонування запас деревини лісових фітоценозів становить від 60 до 255 м³/га. Життєвий стан нами визначений як ослаблений та здоровий (75-89 балів за шкалою В. Ю. Алексєєва).

Стан лісових культурфіточенозів у зоні несприятливих екологічних умов. Лісові КФЦ цієї зони представлені деревними насадженнями міського (урочища «Дніпропетровське шосе», «Кільце Косіора») та санітарно-захисного (територія С33 ПАТ «Арселор Міттал Кривий Ріг») поясів. У насадженнях переважають дуб звичайний (Quercus robur), ясен звичайний (Fraxinus excelsior), клен ясенелистий (Acer negundo) та в'яз гладкий (Ulmus laevis). Усі насадження мають штучне походження з середнім віком 60-80 років. Також слід зазначити, що едафічні умови характеризуються низькім рівнем зволоження (окрім ділянок насаджень СЗ3 ПАТ «Арселор Міттал Кривий Ріг») та дуже значним аеротехногенним забрудненням через наближеність їх території до гірничо-металургійних підприємств міста (табл. 1).

Встановлено, що вертикальна структура лісових КФЦ, які розташовані у зоні несприятливих екологічних умов, визначається добре сформованим I та II ярусами та малорозвиненим III ярусом, а також практично відсутнім чагарниковим ярусом (табл. 2). Трав'янистий ярус на ділянках практично відсутній. Щільність насаджень I-III ярусів коливається від 525 до 1600 шт/га, їх висота - 13-19 м. Показники діаметрів стовбурів становлять від 9 до 29 см. За час функціонування запас деревини дорівнює 120-370 м³/га. Життєвий стан визначається як ослаблений (59-76 балів за шкалою В. Ю. Алексєєва).

\section{Висновки.}

Сучасний стан лісових культурфітоценозів Криворіжжя, які були створені у 30-60 роках XX століття та розташовані у різноманітних екологічних умовах, обумовлюється сукупним впливом антропогенних та природних факторів.

Лісові культурфітоценози Криворіжжя характеризуються несформованою вертикальною структурою (у більшості випадків відсутні яруси підліску та чагарників); ущільненими посадками першого та другого ярусів; невисокими значеннями запасів стовбурної деревини; ослабленим та сильно ослабленим відносним життєвим станом деревостану. 
Отримані нами результати перспективно використовувати для конструювання штучних деревних насаджень в умовах степового клімату та на фоні аеротехногенного забруднення, а також при проведенні фіторекультиваційних і фітомеліоративних робіт у промислових регіонах.

У подальшому доцільно виявити еколого-біогеохімічні маркери, які відображають сучасний стан і подальший розвиток лісових культурфітоценозів в умовах степового клімату та на фоні аеротехногенного забруднення.

\section{Бібліографічні посилання}

1. Алексеев В. A. Диагностика жизненного состояния деревьев и древостоев // Лесоведение. 1989. № 4. С. 51-57.

2. Анучин Н. П. Лесная таксация. Москва. 1977. 522 с.

3. Apmюx B. M. Оптимізація техногенних ландшафтів залізорудних розробок Кривбасу. Вінниця. 2001. 189 с.

4. Белова Н. А., Травлеев А. П. Естественные леса и степные почвы. Днепропетровск 1999. $345 \mathrm{c}$.

5. Бельгард А. Л. Искусственный лес в степи в биогеоценотическом освещении // Вопросы степного лесоведения и лесной рекультивации земель: сборник научных трудов. Днепропетровск. 1986. С. 21-26.

6. Бельгард А. Л. Степное лесоведение. Москва. 1971. 336 с.

7. Грицан Ю. І. Екологічні основи перетворюючого впливу лісової рослинності на степове середовище. Дніпропетровськ. 2000. 300 с.

8. Добровольский И. А. Эколого-биогеоценологические основы оптимизации техногенных ландшафтов степной зоны Украины путем озеленения и облесения: автореф. дис. на соискание ученой степени доктора биол. наук: спец. 03.00.16 «Экология». Днепропетровск. 1979. 62 с.

9. Кучерявий В. П. Фітомеліорація. Львів. 2003. 540 с.

10. Лысый А. Е., Рыжсенко С. А., Козятин И. П. Экологические и социальные проблемы и пути оздоровления крупного промышленного региона (на примере Криворожского железорудного бассейна). Кривой Рог. 2007. 428 с.

11. Погребняк П. С. Общее лесоводство. Москва. 1968. 440 с.

12. Савельева Л. С. Устойчивость деревьев и кустарников в защитных лесных насаждениях. Москва. 1975. 168 с.

13. Савосько В. М. Видовий склад та екоморфний спектр деревно-чагарникових насаджень парку «Веселі Терни» (м. Кривий Ріг) // Інтродукція рослин. 2013. № 2. С. 78-82.

14. Савосько В. М., Квітко М. О. Сучасний стан основних насаджень Довгинцівського дендропарку (м. Кривий Ріг) // Промислова ботаніка. 2014. Вип. 14. С. 106-114.

15. Сірик A. A. Природна стиглість лісових насаджень в степу України // Наукові праці Миколаївського держ. гуманітар. ун-ту імені Петра Могили. Серія Екологія. 2000. Вип. 1. Т. 6. С. 20-22.

16. Сметана М. Г. Екологічний потенціал лісових екосистем південного Криворіжжя // Вісник Криворізького техн. ун-ту. 2006. Вип. 12. С. 277-281.

17. Таран М. А. Фітотрофні міксоміцети техногенно змінених екосистем. Кривий Ріг. 2009. $441 \mathrm{c}$.

18. Термена Б. К. Лісознавство з основами лісівництва. Чернівці. 2005. 160 с.

19. Федоровский В. Д., Мазур А. E. Древесные растения Криворожского ботанического сада: итоги интродукции (за 25 лет). Днепропетровск. 2007. 256 с.

20. Шанда В. И. Теоретичні проблеми екології та біогеоценології. Кривий Ріг. 2013. $247 \mathrm{c}$.

Надійшла до редколегії 23.07.2016 p. 